Plant Pathology Science Vol. 6(2), 2017

\title{
Four Important Oak Diseases in Iran
}

\section{MEHDI SADRAVI ${ }^{\otimes} \&$ NAJMEH MORADI}

Department of Plant Pathology, Yasouj University, Yasouj, Iran ( $\triangle$ Corresponding author: msadravi@yu.ac.ir)

Received: 12.11 .2016

Accepted: 10.06.2017

Sadravi M. \& Moradi N. 2017. Four important oak trees diseases in Iran. Plant Pathology Science 6(2):14-23.

Abstract: Zagros Mountains in the west of Iran and some areas in the north of Iran are covered by oak trees. Four important diseases of Iranian oak trees are charcoal rot, chestnut blight, sudden death and powdery mildew. The symptoms of these diseases and the characteristics of pathogens as well as their prevalence are described in this article. Some strategies for protecting the oak trees from these diseases are also proposed here.

Key words: Oak, Biscogniaxia, Cryphonectria, Phytophthora

$$
\begin{aligned}
& \text { جهار بيمارى مهمم بلوط در ايران } \\
& \text { مهدى صدروى ه ه نجمه مرادى } \\
& \text { كروه كياهيزشكى، دانشخاه ياسوج }
\end{aligned}
$$

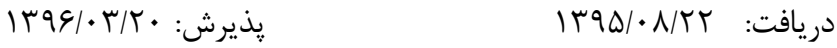

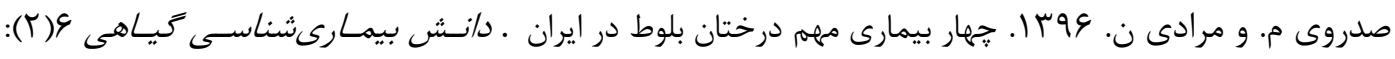

$$
\begin{aligned}
& \text { r } \\
& \text { جكيده : درختان بلوط رشتهكوهاى زاكرس در غرب و مناطقى در شمال ايران را يوشاندهاند. جهار بيمارى مههم انواع } \\
& \text { بلوط در ايران يوسيدگى ذغالى، سوختخى شاهبلوط، مرك ناگمهانى و سفيدك يودرى هستند. نشانههاى اين بيمـارىهـا، }
\end{aligned}
$$

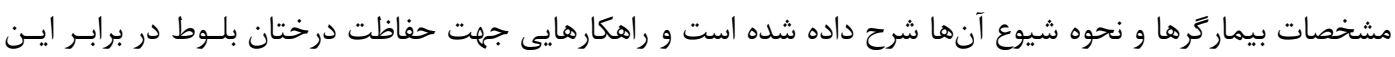

$$
\begin{aligned}
& \text { بيمارىها بيشنهاد شدهاند. } \\
& \text { وازههاى كليدى: بلوط، Phytophthora، Cryphonectria Biscogniaxia } \\
& \text { مقدمه } \\
& \text { در ايران جندين گَونه بلوط سطح وسيعى از رشتهوههاى زاكرس در غرب، جنكلهاى هيركانى و } \\
& \text { ارسباران (شكل () را يوشاندهاند (حسينى و همكاران ^ • ·ץ). كونهاى بلوط در ايران از شمال غربى تا جنوب } \\
& \text { رويشَاههاى بلوط در استانهاى كردستان، كرمانشاه، ايلام، لرستان، خوزستان، جهارمحال و بختيارى و } \\
& \text { msadravi@yu.ac.ir : }
\end{aligned}
$$




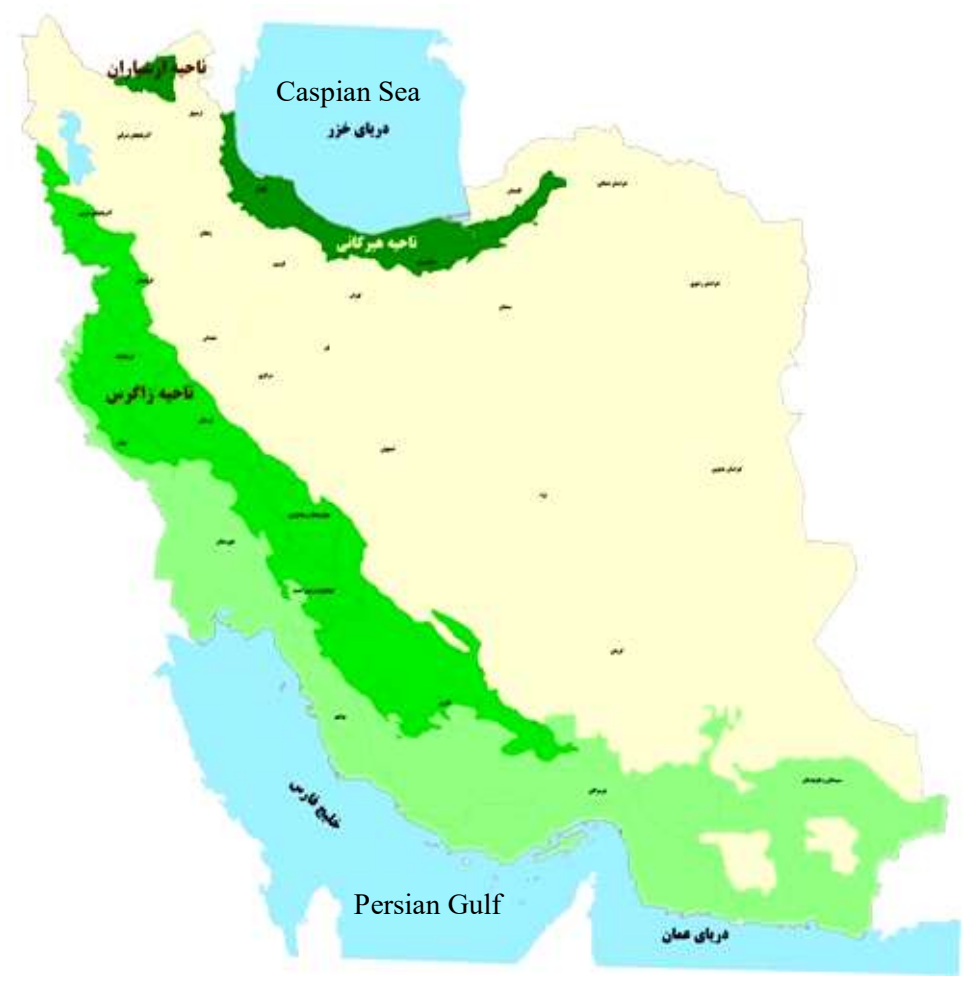

شكل ا- مناطق انتشار (سبز تيره)جنكلهاى بلوط در غرب و شمال ايران (سازمان جنكلها، مراتع و آبخيزدارى كشور).

Figure 1. Distribution areas (Dark green) of oak forests in west and north of Iran.

كهيلويه و بويراحمد هستند (مير ابولفتحى بوسا). جنس بلوط (Quercus) از مهمترين جنسهاى تيره

راش (Fagaceae) به شمار مىآيد. سه كونهى اصلى بلوط غرب شامل: Quercus brantii Lindl، libani Q infectoria Oliv Oliv

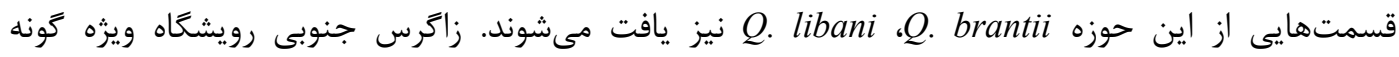
Q. brantii شبهقارجى هستند. شرايط محيطى، ويزگى هاى زنوتيبى و فنوتيجى ميزبان از مهمترين عوامل مؤثر بر گسترش بيمارى در درختان جنكلى مىباشد (Baguskas et al. 2014). نشانهاى اين بيمارىها، مشخصات ريختشناسى، نحوه شيوع ، مناطق انتشار و روش مديريت آنها در اين مقاله شرح داده شدهاند. 


\section{(- (Charcoal Disease) (- ذغالى بلوط)}

نشانههاى بيمارى بهصورت زوال و خزان بىهنگام درختان مىباشد ـ در بهار تعدادى از درختان كـاملاً خشكشده و در تعدادى ديخر يوست درخت بهصورت نوارى از تنه جدا شـده اسـت. تـراوش صـمغ سـفيد در محل شروع آلودگى روى شاخهها و حجم زيادى از صـمغ تيـره روى تنـه درختـان مسـن قابـل توجـه اسـت. همجنين قهوهاى شدن نسوج جوب و دستهجات آوند جوبى ديده مىشود. اين بيمارى بـه صـورت يثمردگى شاخ و برگَها و خروج شيرابه سياه رنگ از قسمتهاى يايين تنه بروز مينمايد، به مرور زمـان شـيرابه افـايش يافته و حالت ذغالى شكل در روى تنه و سياه شدن در زير يوست قابل رؤيت است كه در نهايت منجـر بـه مرگ كامل درخت ميشوند(كرمى و همكاران سوץ|، ميرابوالفتحى بوس ا). اين بيمارى اولـين بـار در ايـران روى Quercus castaneifolia از استان گَلستان و سيس استانهاى ايلام، ، فـارس، كهَّيلويـهـ و بويراحمـد و لرستان ززارش شده است (Mirabolfathy et al. 2011 ، ميرابوالفتحى بوץ|) . اين قارج روى درختان بلـوط منطقه تنگ مهريان استان كهَيلويه و بويراحمد نيز شايع است (شكل ؟). اين بيمارى كه بـهـ زوال يـا مـرى خاموش نيز معروف است روى Q. ilex L. Q. suberi در آفريقا، اسپيانيا، يرتغال، اسلوونى و ايتاليا نيـز شـيوع جشمخير دارد (Jurc and Ogris 2005).

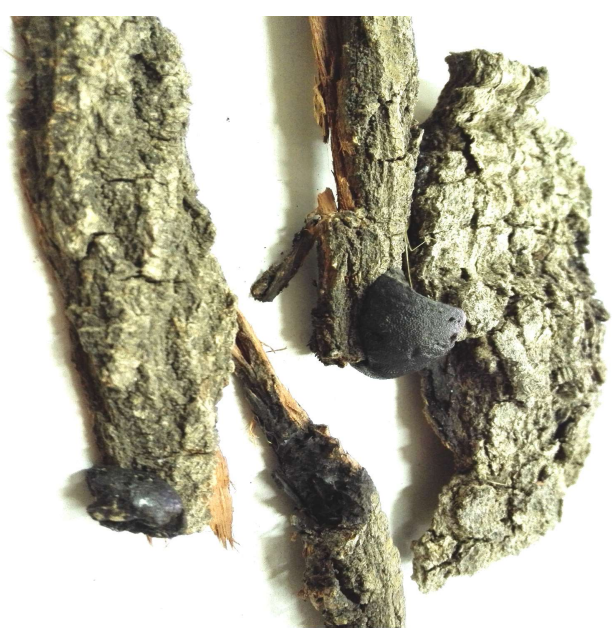

شكل Y -استروماى سياهرنت Biscogniauxia mediterana، عامل ذغـالى بلـوط روى پوسـت تنـه درختـان

$$
\text { خشكيده بلوط در جنوب غرب ايران (اصلى). }
$$

Figure 2. Black stroma of Biscogniauxia mediterana, causal oak charcoal rot disease on bark of dead trees in sowth-west Iran (Original). 
بيمـاركر : قـارج Biscogniauxia mediterranea (De Not.) O. Kuntze از شـاخه Ascomycota اسـت

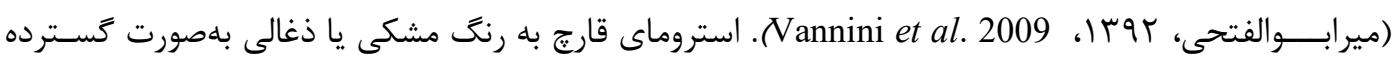
و كشيده و يا نوارى به طول • (- ه سانتىمتر و به ضخامت ؟ -1 ميلى متر روى تنـه درختـان بيمـار تشـكيل مىشود. كنيديومهاى تكسلولى و تخممرغى شكل و شفاف بيماركر در بهار و تابستان منتشر مىشوند و باعث

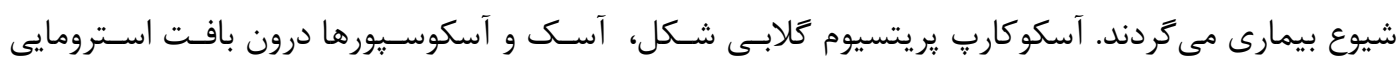

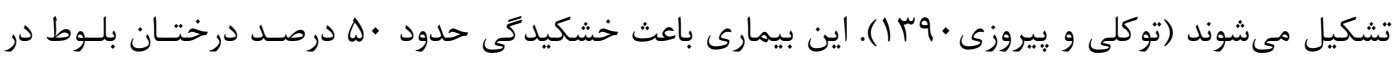
• . . 19 هكتار از جنكل هاى اسلوونى شـده اسـت و درون اسـتروماهاى سـياهرنـق روى تنـه درختـان مـرده، آسكو كاربٍ ير يتسيومى، آسكها و آسكوسيورهاى قارج قابل تشخيص بودهاند (Jurc \& Ogris 2005). دمـاى بهينه براى جوانهزنى هاگها ه درجه سلسيوس است (Parvaneh and Valipour 2012). اين قـارج مرحلـه درونرستى و كمون طولانى دارد كه در اين مرحله نشانههاى بيمارى مشـاهده نمسىشـوند. در شـرايط تـنش خشكى و دماى بالاتر از حد معمول بهصورت مهاجم و سريع عمل مى كند. رابطـهـه بسـيار نزديـك بـين تسنش

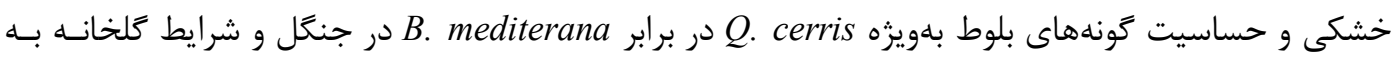
اثبات رسيده است. افزايش عفونتهاى متعدد در كَياه به دليل كلونيزه شدن آونـدها توسـط عامـل بيمـارىزا، باعث كاهش جريان شيره خام و يرٔمردىى و خشكيدگى ميزبان مى گردد. علاوه بـر ايسن هجـوم سوسـكهـاى شاخك بلند (Coleoptera: Cerambycidae)، مانند سوسـى شـاخك بلنـد بلـوط ( Megopis scabricornis (Scopoli و سوسك شاخك بلند رزاسه (Osphranteria coerulescens Redtenbacher)، به درختـان بيمـار، عاملى است كه روند كسترش بيمارى و شدت خسـارت آن را افزايش مسىدهنـد (كرمسى و همكـاران rوبا، (Martin et al. 2005

مrichoderma harzianum مديريت: ياشيدن قارجكش جذبى يروييكونازول يا سوسيانسيون هاگهاى قارج روى طوقه و تنه درختان به محض بروز نشانههاى بيمارى و زخمهــا مسى توانـد بـهـ بهبــود آنهـا كمــ كنـــ. همجِنين مبارزه با سوسكهاى شاخك بلند و هرس شاخههاى خشـكيده كـهـ لارو ايـن سوسـكهـا در آنهـا مستقر هستند در اواخر زمستان و بريدن و ريشه كنى درختان خشك شده، كه منشـا آلـودگى بـراى درختـان

سالم مى گردند، براى مديريت بيمارى توصيه شده است (Karami et al. 2017, Rostamian et al.2017). 


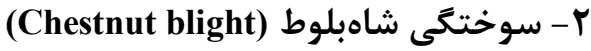

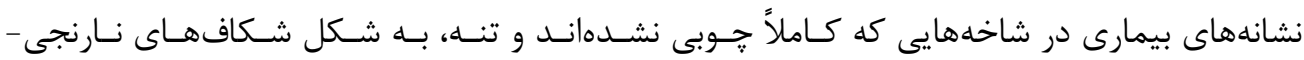

قهوهاى رنت، كمى فرورفته در جهت طولى ظاهر مىشوند. بلهــرور آنهـا شـاخههـا و تنــه را احاطـه كـرده و

زخمهاى عمودى ايجاد مى كنند، كه بهراحتى يوست آنها جدا شده و در زير آنـان ميسـيليوم بـادبزنى شـكل

بيمارگر مشاهده مىشود. به تدريج در بالاى اين زخمها، تمام شاخهها، برگها و ميوهها خشك مىشوند و بـهـ

درخت حالت سوختگى مى دهند (Juhasova et al. 2004).

بيمارگر: Cryphonectria parasitica (Murill) Barr است . ير گنه آن به رنَ زرد- نارنجى، ميسيليوم براق

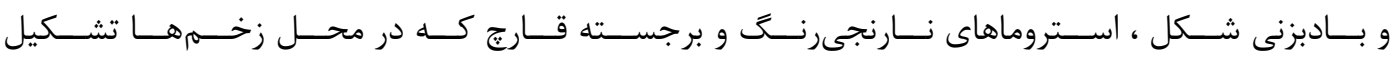

مىشوند، ابتدا حاوى ييكنيديومهايى هستند كه در آنها كنيديومهاى بىرنگ، كشيده تا استوانهاى شكل، بــه

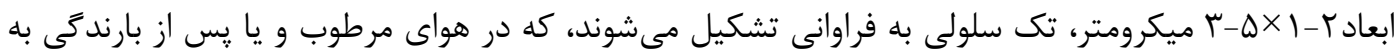

صورت رشتههاى لزج زرد تا نارنجىرنگیى خارج شده و همراه با قطرات باران توام با باد يخش مىشوند و باعث

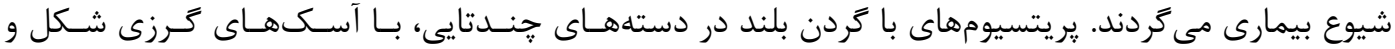

آسكوسيورهاى دوسلولى و بىرنگ، در پاييز و زمستان درون اين استروماها يديد مى آينـد. يـراكنش هـاخهـا

Micales \& Stipes 1987, Locci 2003, Jaynes \& ) توسط باد و بـاران بـه سـاير منـاطق صـورت مسى گيـرد)

(Depalma 1984

مناطق انتشار: اين بيمارى كه براى اولين بار در سال 9.19 ميلادى از باغ گياهشناسـى نيويـورى آمريكـا ، سيس در جنَل هاى شرق آمريكا، كشورهاى ارويايى مانند ايتاليا و غـرب آسـيا گَزارش شـده اسـت، اكنـون كَترش جهانى دارد و تخمين زده مىشود كه در نيمه اول قرن بيستم ميلادى حدود f ميليارد درخـت شـاه بلوط را در آمريكا از بين برده باشد (2003 Locci) ، در استان كيلان شـايع اسـت (قزى و همكـاران M

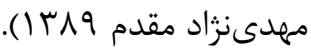

مديريت: مهمترين روش مديريت بيمارى، اسـتفاده از جدايسههـاى كـهمآزار (Hypo-virulent) بيمـاركر، كــه ير گنه سفيدرنگ و كنيديومهاى كوجكترى دارند و آلوده به ويروسى با زنوم dsRNA هستند، است. با يـافتن جدايهاى در جنگل هاى ايتاليا و تكثير و ياشيدن آن روى درختان بيمار در جنگلهاى شرق آمريكا بيمارى به 
خوبى مهار شده است (Bissegger et al.1997). ويروس عامل كممزآرى بيماركر در اين روش از طريق جـوش ريسهاى از جدايه كممزار به جدايه يرآزار منتقل مىشود و در طبيعت گسـترش يافتـهـ و باعثث مهـار بيمـارى مى گردد (Cortesi et al. 2001, Turina \& Rostagno 2007). روش ديگر استفاده از ارقام مقاوم شاهبلوط است، كه در بين ارقام شاهبلوط بعضى ارقام جينى مقاومت زيادى به بيمارى نشان دادهاند، كه از آنها براى اصلاح ارقام تجارتى حساس شاهبلوط آمريكايى استفاده شده است (Locci 2003). (20).

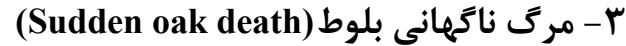

اين بيمارى با ايجـاد زخـمهــيى(Cankers) روى قسـمت يـايينى تنـه درختـان بلـوط، كـه از آنهـا شيرابههاى قرمز تيره تا سياهرنت ترشح مىشود، ظاهر شده و با ايجاد اختلال در سيستم آوندى كياه موجـب زرد و خشك شدن بركما در سرشاخهها و مرى سريع درختان بيمار مىشود. زير زخمها نواحى خالدار تغييـر رنگ يافته بافتهاى درونى يوست قابل مشاهده است. بركها نيز بهصورت گروهى در مدت زمان كمى تغييـر رنك داده و روى شاخهها يزمرده و خشك مىشوند. لكههاى مرده در طول حاشيه برى و ظاهر شـده و تـا دم بركها توسعه مى يابند و سبب از بين رفتن جوانهها مىشوند (Alexander and Swain 2010).

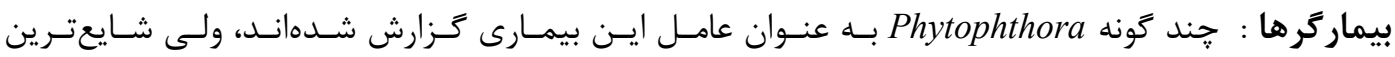
آنها، شبهقارج خاكزى Phytophthora ramorum Werres است. اسيورانزيومهاى آن بيضى تا دوكىشـل،

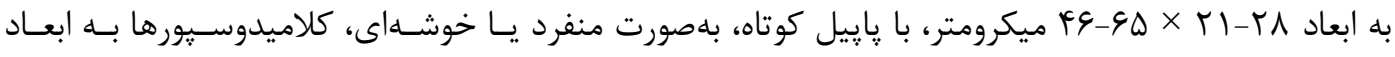
4 \&× •4 ميكرومتر و كرد با ديواره نازك هستند. اين شبهقارج كه هتروتال است در دماى •r درجه سلسيوس توليد ريسه و اسيورانزيوم مى كند، كه آنها در دماى پايين توليد زئوسيور مى كنند و در دماى بـالا بـهــورت مستقيم جوانه مىزنند. سرعت رشد آن در دماى بالاتر از له درجه كند مىشود و توليد كلاميدوسيور مى كند. زئوسيورها در سطح آب يس از باران شنا كرده و باعث انتشار بيمارى مىشوند. كلاميدوسـيورها مسىتوانـــد در خاكهاى آلوده سال هاى طولانى زنده بمانند و موجب انتقـال بيمـارى شـوند. ايـن بيمـاركر دامنـه ميزبـانى 


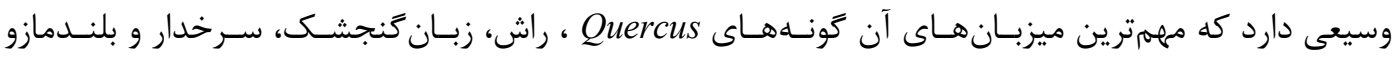
هستند) (Werres et al. 2001) .

مناطق انتشار : اين بيمارى خطرناك در آمريكاى شمالى و بعضى كشورهاى ارويايى شيوع دارد) Alexander

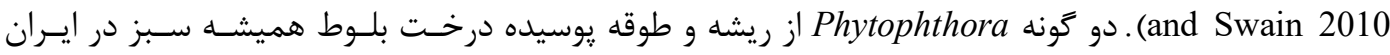

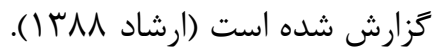
مديريت : حذف درختان خشكيده بهمنظور عدم سـرايت بيمـارى بـه سـاير درختـان، بانكـت بنـدى اراضـى شيبدار براى مهار آبهاى روان يِي از كاشت نهال هاى درختان حساس براى يیشخيرى از گسترش بيمـارى موثر است (Alexander and Swain 2010). يُشيدن سم دانهاى متالاكسيل (ريدوميل) به پِى درختان بيمـار ودر سايهانداز آنها به ميزان ه گرم براى هر مترمربع يِش از بارندگى و يا آبيارى آنها يس از ياشيدن سم را مى توان براى درمان درختان بيمار آزمود.

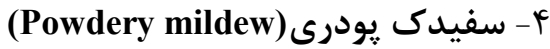

يودر سفيدرنكى روى سطح بركها و جوانهاى شاخههاى جوان ظاهر مىشود، كه مىتواند به زرد شدن و خشكيدگى آنها بيانجامد. بيمارى در آب و هواى خشك هم شيوع مىيابد، ولى بارندگى يا رطوبت نسبى بالا براى ايجاد آلودكى جديد لازم است و بر شدت آن مىافزايند. با وجود اين كه بيمارى درخت را ازبين

$$
\text { نمىبرد، اما رشد رويشى و ميزان ميوه آن كاهش مىيابد. }
$$

بيماركر ها : قـارجهـاى Ehyllactinia ، Erysiphe alphitoides Braun and Takamatsu var. alphitoides Sawadaea tulasnei (Fuck.) g Leveillula taurica (Lev.) Arnaud ، guttata (Wallr. Fr.) Lev. از روى گونهاى Quercus در ايران و جهان كزارش شدهاند (سيهوند و همكاران سوس ا). مناطق انتشار: اين بيمارى در جنكل هاى بلوط در غرب و شمال ايـران، سايركشـورهاى آسـيايى، ارويـايى و آمريكاى شمالى شايع است (سيلوند و همكاران بوس؟). مديريت : معمولا اين بيمارى منجر به خشكيدگى كامل درختان بلوط نمىشود ولى ضمن كاهش رشد رويشى و ميزان محصول آنها باعث افزايش حساسيت درختان بيمار به ساير بيمارىها و آفتها و سرانجام 
زوال بلوط مىشود. در صورت آلودىى شديد درختان به بيمارى مىتوان تاثير قارجشهاى ترىديمورف (كالكسين) و يا استروبيلورينى را در كاهش شدت بيمارى در نهالستانها و يا درختان جوان آزمود.

\section{نتيجه كيرى و وييشنهاد}

درختان بلوط سطح وسيعى از جنحـلهــا در غـرب و شـمال ايـران را تشـكيل دادهانـد. بديـده زوال و

خشكيدكى اين درختان در طى دو دهه اخير در حال كسترش و نابودى اين جنكلها است. اين پيديده ظـاهرا در اثر مجموعهاى از عوامل شامل شيوع بيمارىهاى مهمى مانـــد ذغـالى بلـوط، سـوختخى شـاهبلـوط، مـرى ناكهانى، سفيدك يودرى، گَياه نيمهانكل دارواش و بعضى آفتها است. در ايـن مقالـه نشـانههـاى ايـن تهـار بيمارى و مناطق انتشار آنها شرح داده شده و روشهاى مناسب براى مديريت آنها و حفاظـت و حمايـت از جنكل هاى كشور پِيشنهاد شده است.

\section{References}

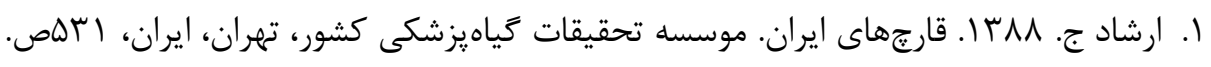

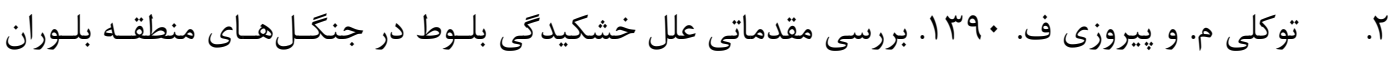
كوهدشت. همايش ملى جنغلهاى زاكرس مركزى، جهاد دانشخاهى، لرستان، آذر •وبا، ص ؟.

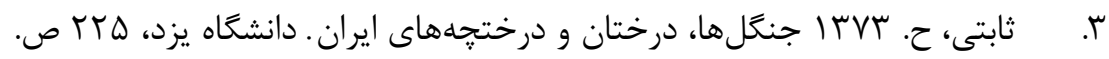
F. سيدوند ك.، درويشنيا م. و بازگير ع. بوس ا. شناسايى قارجهاى Erysiphaceae در گروهى از درختان

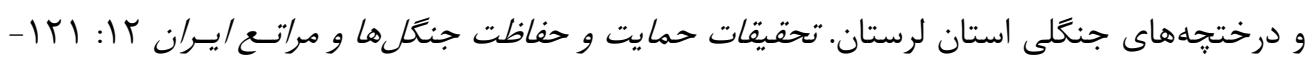

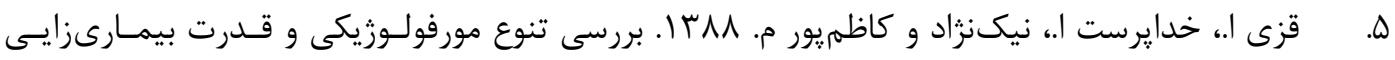
جدايههاى مختلف Cryphonectria parasitica عامل سوختكى شاهبلوط در استان گيلان. بيمارىهاى

$$
\text { كياهى }
$$




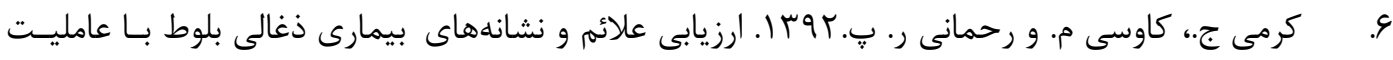

$$
\begin{aligned}
& \text { قارت Biscogniauxia mediterranea و عوامل مؤثر آن بر شيوع و مديرت. مقالات دومين همايش ملى }
\end{aligned}
$$

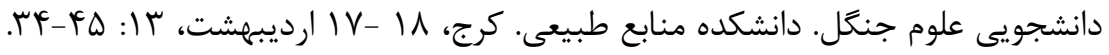

$$
\begin{aligned}
& \text { V. ميرابوالفتحى م. זوسا. شيوع بيمارى ذغـالى درختـان بلـوط و آزاد در جنَـلهـاى البـرز و زاخـرس. }
\end{aligned}
$$

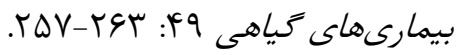

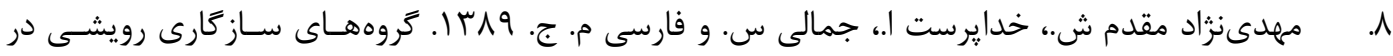

$$
\begin{aligned}
& \text { جمعيتهاى قارج Cryphonectria parasitica عامل سوختخى شاهبلوط در استان گيلان. بيمارىهاى }
\end{aligned}
$$

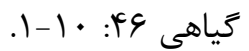

9. Alexander J. M. and Swain S. V. 2010. Sudden Oak death. University of California Agriculture and Natural Resources Program. Davis, CA 95616, 1-8.

10. Baguskas S. A., Peterson S. H., Bookhagen B. and Still C. J. 2014. Evaluating spatial patterns of drought - induced tree mortality in a coastal California pine forest. Forest Ecology and Management 315:43- 53.

11. Bissegger M., Rigling D. and Heiniger U. 1997. Population structure and disease development of Cryphonectria parasitica in European chestnut forests in the presence of natural hypovirulence. Phytopathology 87:50-59.

12. Cortesi P., Mcculloch C. E., Song L. H. and Milgroom M. G. 2001. Genetic control of horizontal virus transmission in the chestnut blight fungus, Cryphonectria parasitica. Genetics 159:107-118.

13. Hosseini, A., Moayeri, M. H. and Haidari, H. 2008. Effect of site elevation on natural regeneration and other characteristics of oak (Quercus brantii) in the Hyanan's Forest, Ilam. Journal of Agriculture Science Natural Resources 15:27-42.

14. Jaynes R. A. and Depalma N. K. 1984. Natural infection of nuts of Castanea dentate by Endothia parasitica. Phytopathology 74:296-299.

15. Juhasova G, Admikova K., Ivanova H. and Kobza M. 2004. Situation of damage caused Cryphonectria parasitica to forest stands and orchards of Castanea sativa by 2001 in Slovakia. Horticultural Science 3:102-108.

16. Jurc D. and Ogris N. 2005. First reported outbreak of charcoal disease caused by Biscogniauxia mediterranea on Turkey oak in Slovenia. Plant Pathology 55:299-299. 
17. Karami J., Kavosi M. R., Babanezhad M. and Kiapasha K. 2017. Integrated management of the charcoal disease by silviculture, chemical and biological methods in forest parks. Journal of Sustainable Forestry https://doi.org/10.1080/10549811.2017.1416642.

18. Locci, R. 2003. Chestnut blight: a epidemic checked by biological control furling. Journal of Science 4:27-45.

19. Martin J., Cabezas J., Buyolo T. and Paton D. 2005. The relationship between Cerambyx spp. damage and subsequent Biscogniauxia mediterranum infection on Quercus suber forests. Forest Ecology and Management, 216:166-174.

20. Marvie M. 2005. Silviculture. University of Tehran Press, Tehran 387p.

21. Micales J. A. and Stipes R. J. 1987. A reexamination of the fungal Genera Cryphonectria parasitica and Endothia. Phytopathology 77:650-654.

22. Mirabolfathy M., Groenewald J. Z. \& Crous P. W. 2011. The occurrence of charcoal disease caused by Biscogniauxia mediterranea on chestnut-leaved oak (Quercus castaneifolia) in the Golestan forests of Iran. Plant Disease 95(7): 876.

23. Parvaneh B. and Valipour M. 2012. Investigation on Effects of Climatic Variables on Zagros Oak Q. Brantii lindl Tree Rings: A Case Study of Shurab Park (Western Iran). World Applied Sciences Journal 17:626- 630

24. Rankovic B., 1997. Hyperparasites of the genus Ampelomyces on powdery mildew fungi in Serbia. Mycopathologia 139:157-164.

25. Rostamian M., Kavosi M. R., Bazgir E. and Babanezhad M. 2017. Charcoal disease (Biscogniauxia mediterranea) control using biological and chemical compounds in vitro. Imperial Journal of Interdisciplinary Research 3(4): 1960-1968.

26. Turina M. Rostagno. 2007. Virus-induced hypovirulence in Cryphonectria parasitica: still an unresolved conundrum. Plant Pathology 89:165-178.

27. Vannini A., Lucero G., Anselmi N. and Vettraino A. M. 2009. Response of endophytic Biscogniauxia mediterranea to variation in leaf water potential of Quercus cerris. Forest Pathology 39: 8-14.

28. Werres S., Marwitz R., veld W., Cock A., Bonants P. J. M., Weerdt M. D., Themann K., Ilieva E. and Baayen R. P. 2001. Phytophthora ramorum sp. nov., a new pathogen on Rhododendron and Viburnum. Mycological Research 105:1155-1165.

29. Zhang L., Churchill A. C. L., Kazmierczak P., Kim D. H. and Alfen N. K., 1993. Hypovirulence - associated traits induced by a mycovirus of Cryphonectria parasitica are mimicked by targeted inactivation of a host gene. Molecular and Cellular Biology 13:59-64. 